\title{
Urinary iron excretion induced by intravenous infusion of deferoxamine in ß-thalassemia homozygous patients
}

E. Boturão-Neto ${ }^{1}$, L.F. Marcopito ${ }^{2}$ and M.A. Zago ${ }^{1}$
Correspondence

M.A. Zago

Departamento de Clínica Médica FMRP, USP

Av. Bandeirantes, 3900

14049-900 Ribeirão Preto, SP

Brasil

Fax: +55-16-633-4009

E-mail: marazago@usp.br

Publication supported by FAPESP

.....................

Received December 10, 2001

Accepted August 22, 2002
1Departamento de Clínica Médica, Faculdade de Medicina de Ribeirão Preto, Universidade de São Paulo, and Banco de Sangue Regional (Hemocentro), Ribeirão Preto, SP, Brasil

${ }^{2}$ Departamento de Medicina Preventiva, Universidade Federal de São Paulo, São Paulo, SP, Brasil

\begin{abstract}
The purpose of the present study was to identify noninvasive methods to evaluate the severity of iron overload in transfusion-dependent $\beta$-thalassemia and the efficiency of intensive intravenous therapy as an additional tool for the treatment of iron-overloaded patients. Iron overload was evaluated for 26 B-thalassemia homozygous patients, and 14 of them were submitted to intensive chelation therapy with high doses of intravenous deferoxamine (DF). Patients were classified into six groups of increasing clinical severity and were divided into compliant and non-compliant patients depending on their adherence to chronic chelation treatment. Several methods were used as indicators of iron overload. Total gain of transfusion iron, plasma ferritin, and urinary iron excretion in response to 20 to $60 \mathrm{mg}$ /day subcutaneous DF for 8 to $12 \mathrm{~h}$ daily are useful to identify iron overload; however, urinary iron excretion in response to $9 \mathrm{~g}$ intravenous DF over $24 \mathrm{~h}$ and the increase of urinary iron excretion induced by high doses of the chelator are more reliable to identify different degrees of iron overload because of their correlation with the clinical grades of secondary hemochromatosis and the significant differences observed between the groups of compliant and non-compliant patients. Finally, the use of 3-9 $\mathrm{g}$ intravenous DF for 6-12 days led to a urinary iron excretion corresponding to 4.1 to $22.4 \%$ of the annual transfusion iron gain. Therefore, continuous intravenous DF at high doses may be an additional treatment for these patients, as a complement to the regular subcutaneous infusion at home, but requires individual planning and close monitoring of adverse reactions.
\end{abstract}

\section{Introduction}

Conservative treatment of $\beta$-thalassemia is based on regular red cell transfusions to maintain the hemoglobin levels close to normal (1). This, however, causes an excessive iron build-up in the organism, culminating in
Key words

- ß-Thalassemia

- Iron overload

- Deferoxamine

- Iron excretion

..................... the installation of secondary hemochromatosis that causes endocrine, hepatic and cardiac dysfunction (2-5). Long and worldwide experience has proven the efficiency of prophylaxis of iron overload based on the subcutaneous infusion of deferoxamine (DF) combined with oral vitamin $\mathrm{C}(1,4,6)$. Both 
clinical and laboratory data indicate the benefits of this treatment (6-11) and an increase in life expectancy of compliant patients $(5,12-$ 14). Since many patients eventually develop cardiac or endocrine complications, it has been suggested that the addition of high intravenous doses of DF may help prevent or delay the development of hemochromatosis $(3,15,16)$.

The purpose of the present study was to identify noninvasive methods to determine the degree of iron overload in transfusiondependent $\beta$-thalassemia homozygotes and to evaluate the efficiency of a more intensive therapeutic approach to induce excretion of large quantities of iron as an additional tool for the treatment of iron-overloaded patients.

\section{Patients and Methods}

\section{Patients}

The study included 26 transfusiondependent $\beta$-thalassemia homozygotes (12 females and 14 males, 25 with thalassemia major and one with thalassemia intermedia), who had been under regular treatment for at least three years at the Hemotherapy and Hematology Service of the University Hospital (Table 1). The study was reviewed and approved by the Hospital Ethics Committee.

Since the beginning of treatment, all thalassemia major patients were kept on a transfusion regimen to maintain hemoglobin levels above $10 \mathrm{~g} / \mathrm{dl}$, and iron chelation with

Table 1. Clinical and laboratory features of the thalassemia patients.

\begin{tabular}{|c|c|c|c|c|c|c|c|c|c|c|c|}
\hline $\begin{array}{l}\text { Patient } \\
\text { No. }\end{array}$ & $\begin{array}{l}\text { Age } \\
\text { (years) }\end{array}$ & $\begin{array}{l}\text { Weight } \\
(\mathrm{kg})\end{array}$ & Symptoms & $\begin{array}{l}\text { Spleen } \\
\text { (cm) }\end{array}$ & Compliant & $\begin{array}{l}\text { Glucose } \\
\text { (mg/dl) }\end{array}$ & GTT & ALT (U/I) & $\mathrm{HCV}$ & $\begin{array}{c}\text { Cardiac } \\
\text { abnormalities }\end{array}$ & $\begin{array}{l}\text { Clinical } \\
\text { grade }\end{array}$ \\
\hline 1 & 4 & 22 & Absent & 4 & Yes & 94 & - & 17.0 & - & - & 0 \\
\hline 2 & 4 & 20 & Absent & 3 & Yes & 83 & - & 42.5 & - & - & I \\
\hline 3 & 5 & 18 & Absent & 3 & Yes & 84 & - & 60.9 & - & - & I \\
\hline 4 & 5 & 20 & Absent & 3 & Yes & 96 & - & 50.0 & - & - & I \\
\hline 5 & 6 & 22 & Absent & $\mathrm{np}$ & Yes & 83 & - & 20.0 & + & - & 0 \\
\hline 6 & 6 & 21 & Absent & $\mathrm{np}$ & Yes & 84 & - & 19.1 & - & - & 0 \\
\hline 7 & 9 & 29 & Absent & $\mathrm{np}$ & Yes & 105 & Normal & 27.2 & - & - & 0 \\
\hline 8 & 10 & 27 & Absent & $\mathrm{np}$ & Yes & 88 & Normal & 120.5 & - & - & I \\
\hline 9 & 10 & 37 & Absent & 4 & Yes & 95 & Normal & 28.5 & + & - & 0 \\
\hline 10 & 12 & 44 & Absent & splx & Yes & 87 & Normal & 58.2 & - & + & ॥ \\
\hline 11 & 13 & 40 & $\mathrm{CHF}$ & $\mathrm{np}$ & No & 98 & Normal & 89.0 & + & ++ & IV \\
\hline 12 & 13 & 29 & Absent & 1 & No & 85 & Normal & 66.0 & + & + & $\|$ \\
\hline 13 & 13 & 39 & Absent & 3 & Yes & 89 & Normal & 25.0 & - & - & 0 \\
\hline 14 & 13 & 38 & Absent & splx & No & 86 & Normal & 84.5 & - & - & । \\
\hline 15 & 14 & 41 & Absent & 3 & Yes & 97 & Normal & 28.2 & + & - & 0 \\
\hline 16 & 14 & 34 & Absent & $\mathrm{np}$ & Yes & 91 & Normal & 15.5 & - & + & । \\
\hline 17 & 15 & 50 & Absent & splx & Yes & 98 & Normal & 22.0 & - & ++ & $\|$ \\
\hline 18 & 16 & 49 & Absent & splx & Yes & 100 & Normal & 69.5 & indeter & - & I \\
\hline 19 & 17 & 43 & Bone deformity & splx & No & 97 & Normal & 64.5 & indeter & ++ & III \\
\hline 20 & 19 & 46 & Bone deformity & splx & No & 85 & Normal & 24.0 & - & ++ & $\|$ \\
\hline 21 & 20 & 47 & $\mathrm{CHF}$ and DM & splx & No & $300 / 513$ & - & 35.0 & - & + & III \\
\hline 22 & 21 & 50 & $\mathrm{CHF}$ and $\mathrm{DM}$ & splx & No & $444 / 420$ & - & 39.0 & + & ++ & V \\
\hline 23 & 21 & 53 & Bone deformity & splx & Yes & $169 / 154$ & Diabetic & 25.5 & indeter & ++ & III \\
\hline 24 & 25 & 48 & Bone deformity & splx & Yes & 106 & Normal & 38.2 & + & ++ & III \\
\hline 25 & 28 & 49 & Bone deformity & splx & No & 100 & Normal & 36.0 & + & + & $\|$ \\
\hline $26^{*}$ & 50 & 57 & $\begin{array}{l}\text { Leg ulcers and } \\
\text { bone deformity }\end{array}$ & splx & No & 92 & Intolerant & 43.0 & + & + & III \\
\hline
\end{tabular}

CHF: congestive heart failure; DM: diabetes mellitus; spleen: measured below the costal margin; np: non-palpable; splx: splenectomy; GTT: glucose tolerance test; ALT: alanine aminotransferase; HCV: anti-HCV antibody; indeter: indeterminate; cardiac abnormalities: see Table 2. *Thalassemia intermedia. 
subcutaneous DF (20 to $60 \mathrm{mg} \mathrm{kg}^{-1}$ day $^{-1}$ ) administered with a portable pump for 8 to $12 \mathrm{~h}$ daily, at least 5 days a week, and $100 \mathrm{mg}$ vitamin $C$ daily. The thalassemia intermedia patient developed complications late in life and has been transfused regularly since the end of the fourth decade of life.

On the basis of the information obtained by questioning the patients and the families on the occasion of every monthly visit, the patients were divided into two groups: 17 compliant with treatment (patients who used at least $80 \%$ of the prescribed DF dose) and 9 non-compliant patients (Table 1). Three patients (patients 11,21 and 22) had congestive heart failure and two of them died (patients 11 and 22). Patients 21 and 22 also presented the classical symptoms of diabetes mellitus.

In addition to patients 21 and 22 who had overt clinical diabetes mellitus, patient 23 fulfilled laboratory criteria for diabetes and patient 26, with thalassemia intermedia, had an "intolerant" glucose tolerance test, according to the criteria of the National Diabetes Data Group (17). All patients presented normal prothrombin time (international normalized ratio between 0.9 and 1.2), but 14 patients $(53.8 \%)$ presented elevated serum alanine aminotransferase (ALT). No patient had a positive test for HBsAg but $34.6 \%$ were positive for anti-hepatitis $C$ virus (Table 1 ), and all patients were negative for antiHIV 1 and anti-HTLV 1 antibodies.

Evaluation of cardiac function (Table 2) revealed that 6 patients $(23.0 \%)$ had an enlarged cardiac shadow in the chest X-ray, 9 patients $(34.6 \%)$ had electrocardiographic changes, and 10 patients (38.5\%) had morphological or functional changes detected by two-dimensional Doppler echocardiography.

\section{Methods}

Serum iron, total iron-binding capacity, transferrin saturation, plasma ferritin, and urinary iron. Serum iron, total iron-binding capacity and transferrin saturation were measured by the alpha-dipyridyl method $(18,19)$. Plasma ferritin was determined using an immunoenzymatic method (Ferrizyme kit, Abbott Laboratories, Chicago, IL, USA). Urinary iron excretion was measured within $24 \mathrm{~h}$ after urinary collection (4 to 6 samples per patient, except for one patient who had only two samples) by the bathophenanthroline colorimetric method $(20,21)$.

Daily and annual urinary iron excretion.

Table 2. Assessment of the cardiac function of thalassemia patients.

\begin{tabular}{|c|c|c|c|}
\hline Patient No. & Chest X-ray E & Electrocardiogram at res & st 2-D Doppler echocardiogram \\
\hline 1 & Normal & Normal & Normal \\
\hline 2 & Normal & Normal & Normal \\
\hline 3 & Normal & Normal & Normal \\
\hline 4 & Normal & Normal & Normal \\
\hline 5 & Normal & Normal & Normal \\
\hline 6 & Normal & Normal & Normal \\
\hline 7 & Normal & Normal & Normal \\
\hline 8 & Normal & Normal & Normal \\
\hline 9 & Normal & Normal & Normal \\
\hline 10 & Normal & Normal & Global cardiac enlargement + \\
\hline 11 & Cardiomegaly ++ & DAVR and LVO & $\begin{array}{r}\text { Global cardiac enlargement }++ \text {, } \\
\text { diffuse LV hypokinesia }++ \text {, } \\
\text { depressed LV systolic function, } \\
\text { and mitral regurgitation + }\end{array}$ \\
\hline 12 & Normal & Normal & LA enlargement + \\
\hline 13 & Normal & Normal & Normal \\
\hline 14 & Normal & Normal & Normal \\
\hline 15 & Normal & Normal & Normal \\
\hline 16 & Normal & Normal & LA enlargement + \\
\hline 17 & LV enlargement & LVO & $\begin{array}{l}\text { Global cardiac enlargement }+ \text {, } \\
\text { and diffuse LV hypokinesia }+\end{array}$ \\
\hline 18 & Normal & Normal & Normal \\
\hline 19 & Cardiomegaly + & DAVR and LVO & LA and LV enlargement ++ \\
\hline 20 & Normal & DAVR and LVO & Global cardiac enlargement + \\
\hline 21 & Normal & DAVR & Normal \\
\hline 22 & Cardiomegaly ++ & $\begin{array}{l}\text { DAVR, HFAF, and } \\
\text { low ORS amplitude }\end{array}$ & $\begin{array}{r}\mathrm{LA}, \mathrm{LV} \text { and } \mathrm{RV} \text { enlargement }++, \\
\text { tricuspid regurgitation }++, \\
\text { and diffuse LV hypokinesia }++\end{array}$ \\
\hline 23 & Normal & 1st grade RBB & LA and LV enlargement + \\
\hline 24 & Cardiomegaly ++ & LAO and LVO & $\begin{array}{c}\mathrm{LA} \text { and } \mathrm{LV} \text { enlargement }+ \text {, and } \\
\text { mitral regurgitation }+\end{array}$ \\
\hline 25 & Normal & DAVR & Normal \\
\hline 26 & LV enlargement & Normal & Normal \\
\hline
\end{tabular}

LV: left ventricle; DAVR: diffuse abnormalities of ventricular repolarization; LVO: left ventricle overload; HFAF: high frequency atrial fibrillation; RBB: right branch block; LAO: left atrium overload; LA: left atrium; RV: right ventricle; +: discrete; ++: moderate. 
The daily urinary iron loss was estimated from the urinary iron measurement. Since DF was used 5 days a week, the average urinary iron excretion of each patient, measured on the days when they applied the subcutaneous chelator at home, was multiplied by $5 / 7$. The annual urinary iron excretion was obtained by multiplying the average daily excretion by 365 .

Total and annual weight of red cells transfused. Patients were transfused with packed red cells. The hematocrit of 38 units of red cell concentrates obtained at the time of transfusion was $0.85 \pm 0.063$ (mean $\pm \mathrm{SD}$ ). The weight of red cells transfused annually was calculated from this value and averaged over the three-year period. Retrospective data were retrieved from the blood bank files to calculate the total amount of red cells received by the patient over his whole life.

Daily and annual parenteral iron gains, and total transfusional iron. Daily and annual parenteral iron gains and total transfusional iron load were calculated from the weight of red cells transfused, since $1 \mathrm{ml}$ of red cells contains approximately $1 \mathrm{mg}$ of iron (3).

Fecal iron excretion. Measurement of fecal iron excretion was not performed in the present study. The literature data are scarce and ranged from 10 to $50 \%$ of the urinary excretion with an intramuscular or subcutaneous DF dose of $500 \mathrm{mg}$ or $20 \mathrm{mg} / \mathrm{kg}$ in 21 patients with iron overload (22-27), and from 49 to $65 \%$ for DF administered intravenously to four iron-overloaded patients (27). Thus, to calculate iron balance, we used the average obtained from the extreme values of 10 to $50 \%$ total iron excreted into the feces.

Annual iron balance. The annual iron balance was calculated from the daily parenteral iron gain (via transfusions), minus the measured urinary iron losses and the estimated biliary loss (fecal excretion). Gastrointestinal iron absorption was not taken into account since it is minimal under these conditions $(3,28)$.
Clinical severity grades. Each patient was allocated to a clinical grade group on the basis of the clinical severity of the disease, evaluated by the following criteria: i) cardiac manifestations: absence of changes, 0 point; presence of cardiac heart failure, 1 point; changes in resting electrocardiogram, 1 point; image changes (2-D Doppler echocardiogram or chest $\mathrm{X}$-ray), 1 point; ii) endocrine manifestations: absence of changes, 0 point; glucose intolerance or diabetes mellitus, 1 point; iii) hepatic manifestations: absence of changes, 0 point; increase of serum ALT, 1 point.

High-dose intravenous chelation. Fourteen patients aged $>12$ years were submitted to a protocol for intensive iron chelation with continuous intravenous infusion of DF during hospitalization consisting of the following steps: a) daily, 24-h urine collection for determination of urinary iron excretion; b) on the first day, no medication was given so that basal urinary iron excretion could be determined; c) on the second day, the patient received a standard "bolus" dose of $0.5 \mathrm{~g}$ DF intramuscularly together with $100 \mathrm{mg}$ vitamin C per os; d) on the subsequent days, the patient received increasing doses of 3, 6 and $9 \mathrm{~g}$ DF in 2 liters of $0.9 \%$ saline, given as a continuous 24-h intravenous infusion, together with a $100 \mathrm{mg}$ oral supplement of vitamin $C$; e) each DF dose was used for 1-4 days before increasing to the next level; f) during hospitalization, close clinical monitoring was carried out, especially for ophthalmic, audiologic and pulmonary complications.

\section{Statistical analysis}

Nonparametric methods were used for statistical analysis of the results: Spearman correlation coefficient, Mann-Whitney rank sum test and Fisher's exact test. Logistic regression (multivariate analysis) was used to evaluate the possible effects of the relevant variables as a whole. 


\section{Results}

Results of the iron balance studies for 26 patients are summarized in Table 3. Serum iron concentrations ranged from 161.5 to $289.0 \mu \mathrm{g} / \mathrm{dl}$ (median 193.5). Transferrin saturation ranged from 64.7 to $99.7 \%$ (median 88.6) and was correlated positively with patient age $(\mathrm{r}=0.508, \mathrm{P}<0.01)$. The individual mean plasma ferritin values (averages of 2-4 measurements per patient) ranged from 1,536 to $13,525 \mathrm{ng} / \mathrm{ml}$ (median 3,787). There was a significant correlation of plasma ferritin with age $(\mathrm{r}=0.458, \mathrm{P}<0.05)$ and with ALT $(\mathrm{r}=$ $0.400, \mathrm{P}<0.05)$. Daily urinary iron excretion induced by subcutaneous DF at home ranged from 4.9 to $48.3 \mathrm{mg} / 24 \mathrm{~h}$ (median 15.1). These values correlated positively with pa- tient age $(\mathrm{r}=0.468, \mathrm{P}<0.05)$ and with plasma ferritin levels $(r=0.472, P<0.05)$. The average excretion obtained with subcutaneous DF was significantly higher in patients with clinical grades III to $\mathrm{V}$ than in patients with grades 0 to II $(\mathrm{P}<0.05)$. The total transfusional iron gain ranged from 0.18 to 2.27 $\mathrm{g} / \mathrm{kg}$ body weight (median 0.99 ). There was a significant positive correlation of transfusional iron gain with plasma ferritin levels $(\mathrm{r}=0.517, \mathrm{P}<0.01)$. The individual average value of the annual balance corrected for body weight ranged from -0.25 to $0.09 \mathrm{~g} / \mathrm{kg}$ body weight (median 0.0027) (Table 3). There was a negative correlation between annual balance and plasma ferritin levels $(\mathrm{r}=$ $-0.405, \mathrm{P}<0.05)$. Patient classification into grades of clinical severity presented a sig-

\begin{tabular}{|c|c|c|c|c|c|c|c|c|}
\hline $\begin{array}{l}\text { Patient } \\
\text { No. }\end{array}$ & $\begin{array}{c}\text { Age } \\
\text { (years) }\end{array}$ & $\begin{array}{l}\text { Follow-up } \\
\text { (years) }\end{array}$ & $\begin{array}{l}\text { Serum iron } \\
(\mu \mathrm{g} / \mathrm{dl})\end{array}$ & $\begin{array}{l}\text { Transferrin } \\
\text { saturation } \\
(\%)\end{array}$ & $\begin{array}{l}\text { Plasma ferritin } \\
\text { (ng/ml) }\end{array}$ & $\begin{array}{l}\text { Urinary iron } \\
(\mathrm{mg} / 24 \mathrm{~h})\end{array}$ & $\begin{array}{l}\text { Corrected transfusion } \\
\text { total iron gain } \\
(\mathrm{g} / \mathrm{kg})^{1}\end{array}$ & $\begin{array}{c}\text { Corrected } \\
\text { average iron annual } \\
\text { balance }\left(\mathrm{g} \mathrm{kg}^{-1} \text { year-1 }\right)^{1}\end{array}$ \\
\hline 1 & 4 & 3 & 182.0 & 96.0 & 1,536 & 7.26 & 0.53 & 0.021 \\
\hline 2 & 4 & 4 & 202.0 & 76.2 & 3,046 & 11.93 & 0.73 & -0.050 \\
\hline 3 & 5 & 2 & 170.5 & 69.2 & 1,627 & 5.74 & 0.58 & 0.093 \\
\hline 4 & 5 & 2 & 271.0 & 89.4 & 2,973 & 17.87 & 0.45 & -0.164 \\
\hline 5 & 6 & 6 & 185.5 & 81.5 & 3,430 & 6.77 & 1.01 & 0.067 \\
\hline 6 & 6 & 4 & 196.3 & 68.8 & 2,890 & 4.90 & 0.72 & 0.067 \\
\hline 7 & 9 & 2 & 174.0 & 84.5 & 1,835 & 9.91 & 0.44 & 0.024 \\
\hline 8 & 10 & 9 & 169.5 & 69.3 & 3,819 & 9.65 & 1.46 & 0.040 \\
\hline 9 & 10 & 9 & 289.0 & 92.6 & 2,211 & 9.28 & 1.15 & 0.061 \\
\hline 10 & 12 & 6 & 176.5 & 73.7 & 3,759 & 20.35 & 1.09 & -0.003 \\
\hline 11 & 13 & 12 & 190.7 & 64.7 & 5,017 & 24.50 & 1.56 & -0.100 \\
\hline 12 & 13 & 12 & 246.5 & 96.5 & 13,525 & 15.31 & 1.72 & -0.032 \\
\hline 13 & 13 & 9 & 190.5 & 97.0 & 3,994 & 18.97 & 1.36 & -0.016 \\
\hline 14 & 13 & 11 & 183.0 & 86.5 & 7,011 & 12.04 & 1.63 & 0.084 \\
\hline 15 & 14 & 4 & 184.5 & 93.2 & 3,699 & 19.25 & 0.75 & -0.028 \\
\hline 16 & 14 & 7 & 199.0 & 88.0 & 3,957 & 15.10 & 1.25 & -0.007 \\
\hline 17 & 15 & 13 & 210.9 & 87.7 & 1,950 & 8.73 & 1.42 & 0.084 \\
\hline 18 & 16 & 4 & 248.5 & 96.4 & 4,375 & 48.35 & 0.64 & -0.252 \\
\hline 19 & 17 & 0.5 & 185.0 & 98.4 & 3,816 & - & - & - \\
\hline 20 & 19 & 1 & 161.5 & 89.0 & 5,512 & 18.19 & 0.18 & -0.012 \\
\hline 21 & 20 & 18 & 227.3 & 96.5 & 4,092 & 23.42 & 1.98 & -0.056 \\
\hline 22 & 21 & 19 & 270.0 & 95.8 & 5,356 & 29.30 & 2.27 & -0.079 \\
\hline 23 & 21 & 4 & 265.0 & 82.4 & 1,797 & 19.91 & 0.76 & 0.007 \\
\hline 24 & 25 & 4 & 270.5 & 97.3 & 1,746 & 10.97 & 0.72 & 0.059 \\
\hline 25 & 28 & 11 & 186.7 & 99.7 & 5,756 & 8.73 & 1.03 & 0.051 \\
\hline 26 & 50 & 12 & 219.3 & 88.3 & 6,400 & 17.43 & 0.98 & -0.006 \\
\hline
\end{tabular}

Patients received 20 to $60 \mathrm{mg} \mathrm{DF} /$ day for 8 to $12 \mathrm{~h}$ daily.

${ }^{1} \mathrm{~kg}$ body weight. 
nificant positive correlation with age $(\mathrm{r}=$ 0.695, $\mathrm{P}<0.001)$.

The proportion of compliant patients was higher among patients with clinical grades 0 to II than among patients with grades III to $\mathrm{V}$ $(\mathrm{P}<0.05)$. Table 4 displays the comparison of the main clinical and laboratory data between compliant and non-compliant patients under DF therapy. Patients classified as noncompliant were older than compliant patients $(\mathrm{P}<0.01)$, and included a higher proportion of cardiac abnormalities $(\mathrm{P}<0.01)$. Plasma ferritin levels were significantly higher in the group of non-compliant patients than in the compliant group $(\mathrm{P}<0.01)$. The compliant patients presented a lower transfusional iron load than the non-compliant patients $(\mathrm{P}<0.05)$.

A subgroup of 14 patients, 8 males and 6 females, ranging in age from 13 to 50 years (median 16.5), was submitted to intensive iron chelation with intravenous DF for 8 to 14 days (median 12). The urinary iron excretion induced by a single "bolus" intramuscular injection of $0.5 \mathrm{~g}$ DF ranged from 3.8 to $17.1 \mathrm{mg} / 24 \mathrm{~h}$ (median 8.4), and no correlation was observed with clinical grade, com- pliance or patient age. The excretion induced by continuous intravenous injection of DF at the doses of 3, 6 and $9 \mathrm{~g} / 24 \mathrm{~h}$ ranged from 24.4 to $89.6 \mathrm{mg} / 24 \mathrm{~h}$ (median 37.3), from 16.8 to $136.9 \mathrm{mg} / 24 \mathrm{~h}$ (median 55.9), and from 49.4 to $163.2 \mathrm{mg} / 24 \mathrm{~h}$ (median 61.3), respectively (Figure 1). The average excretion obtained with 6 and 9 g DF was significantly higher in patients with clinical grades III to V compared to patients with grades 0 to II $(\mathrm{P}<0.05$ for both concentrations). At the dose of $9 \mathrm{~g} \mathrm{DF}$, the urinary iron excretion was significantly higher in noncompliant patients than in the compliant group $(\mathrm{P}<0.01)$. No side effect was detected as a result of DF use, either in the chronic chelation therapy or in the high-dose chelation approach.

The increase in urinary iron excretion obtained with $6 \mathrm{~g}$ DF over the excretion obtained with $3 \mathrm{~g}$ DF ranged from -7.60 to $51.80 \mathrm{mg}$ iron/24 h (median 16.9), whereas the increase in urinary iron excretion obtained with $9 \mathrm{~g}$ (maximum dose) of DF as compared with excretion obtained with $3 \mathrm{~g}$ (minimum dose) of DF ranged from -5.9 to $78.1 \mathrm{mg}$ iron/24 h (median 28.7) (Figure 2).

Table 4. Comparison of the major clinical and laboratory data of compliant and non-compliant patients treated with deferoxamine (DF).

\begin{tabular}{|c|c|c|}
\hline & Compliant & Non-compliant \\
\hline Patients (N) & 17 & 9 \\
\hline Age (years) & $4-24(10)^{1 *}$ & $13-50(19)$ \\
\hline Diabetes or glucose intolerance & $3 / 17^{2}$ & $1 / 9$ \\
\hline Elevated ALT & $7 / 17$ & $7 / 9$ \\
\hline Cardiac abnormality & $5 / 17^{*}$ & $8 / 9$ \\
\hline Serum iron $(\mu \mathrm{g} / \mathrm{dl})$ & $169.5-289.0(196.3)$ & $161.5-270.0(190.7)$ \\
\hline Transferrin saturation (\%) & $68.8-97.3(87.7)$ & $64.7-99.7(95.8)$ \\
\hline Plasma ferritin (ng/ml) & $1,536-4,375(2,973)^{*}$ & $3,816-13,525(5,512)$ \\
\hline Total iron gain $(\mathrm{g} / \mathrm{kg})$ & $0.44-1.46(0.75)^{*}$ & $0.18-2.27(1.59)$ \\
\hline Annual iron balance $\left(\mathrm{g} \mathrm{kg}^{-1}\right.$ year-1) & $-0.252-0.093(0.024)$ & $-0.100-0.084(-0.022)$ \\
\hline Urinary iron excretion (3 g DF sc) (mg/24 h) & $4.9-48.3(11.9)$ & $8.7-29.3(17.8)$ \\
\hline Urinary iron excretion (6 g DF im) (mg/24 h) & $3.8-12.5(6.2)$ & $5.2-17.1(8.5)$ \\
\hline Urinary iron excretion (9 g DF iv) (mg/24 h) & $49.4-58.5(53.1)^{*}$ & $52.5-163.2(76.6)$ \\
\hline Increase of urinary iron excretion $(\mathrm{mg} / 24 \mathrm{~h})^{3}$ & $-5.9-25.1(20.0)^{*}$ & $4.2-78.1(41.0)$ \\
\hline
\end{tabular}


These differences presented a significant positive correlation with the total transfusional iron gain corrected for body weight $(\mathrm{r}=0.566, \mathrm{P}<0.05$ for $6 \mathrm{~g} \mathrm{DF}$ and $\mathrm{r}=0.630$, $\mathrm{P}<0.05$ for $9 \mathrm{~g} \mathrm{DF}$, respectively) and the clinical severity grades $(\mathrm{P}<0.05$ for both). For the $9 \mathrm{~g}$ DF infusion, the non-compliant group presented a larger difference between the iron excretion achieved by the maximum and minimum intravenous DF doses than the compliant group $(\mathrm{P}<0.05)$.

Multivariate analysis indicated that the only variable able to predict compliance was plasma ferritin: levels $>4,100 \mathrm{ng} / \mathrm{ml}$ presented a negative correlation with compliance $(\mathrm{OR}=0.18,95 \%$ CI: 0.001-0.231, $\mathrm{P}=$ 0.002). A parameter that predicted clinical severity was the increase in urinary iron excretion obtained with $9 \mathrm{~g}$ DF as compared with the excretion obtained with $3 \mathrm{~g}$ DF: levels $>28.5 \mathrm{mg} / 24 \mathrm{~h}$ presented a positive correlation with clinical grade $(\mathrm{OR}=15.0$, $95 \%$ CI: 1.03-218, $\mathrm{P}=0.047$ ).

Urinary iron excretion during intensive chelation therapy induced by a total of 45 to $90 \mathrm{~g}$ intravenous DF over a period of 6 to 12 days ranged from 0.25 to $1.77 \mathrm{~g}$ iron (median 0.54 ). These values correspond to 4.1 to $22.4 \%$ (median 7.5 ) of the iron accumulated by transfusion in one year (Table 5 ).

\section{Discussion}

The present study was performed on patients with a well-defined and heterogeneous clinical profile that allowed the comparison between non-compliant patients with a more severe clinical picture, indicated by a higher clinical grade, and the compliant group with a lower clinical grade.

At present, iron overload can be evaluated by several direct or indirect methods $(1,21,29)$. Measurement of iron concentration in hepatic tissue obtained by biopsy is a more accurate indicator of the grade of tissue iron overload $(21,29,30)$. However, it is an invasive procedure subject to specific indi- cations. Magnetic resonance of liver and heart is also used for evaluation of iron overload $(7,29)$. As an alternative, we used the clinical complications arising from the excessive tissue iron, the total amount of transfusional iron accumulated over the years corrected for body weight and compliance with chelation therapy as indicators of the grade of iron overload. The data on total transfusional iron gain derived from the transfusion records showed a large iron overload, which, for many patients, exceeded the lethal threshold of $1 \mathrm{~g}$ iron $/ \mathrm{kg}$ body weight (28). In spite of this huge iron input over the years, all but two patients remain alive, a
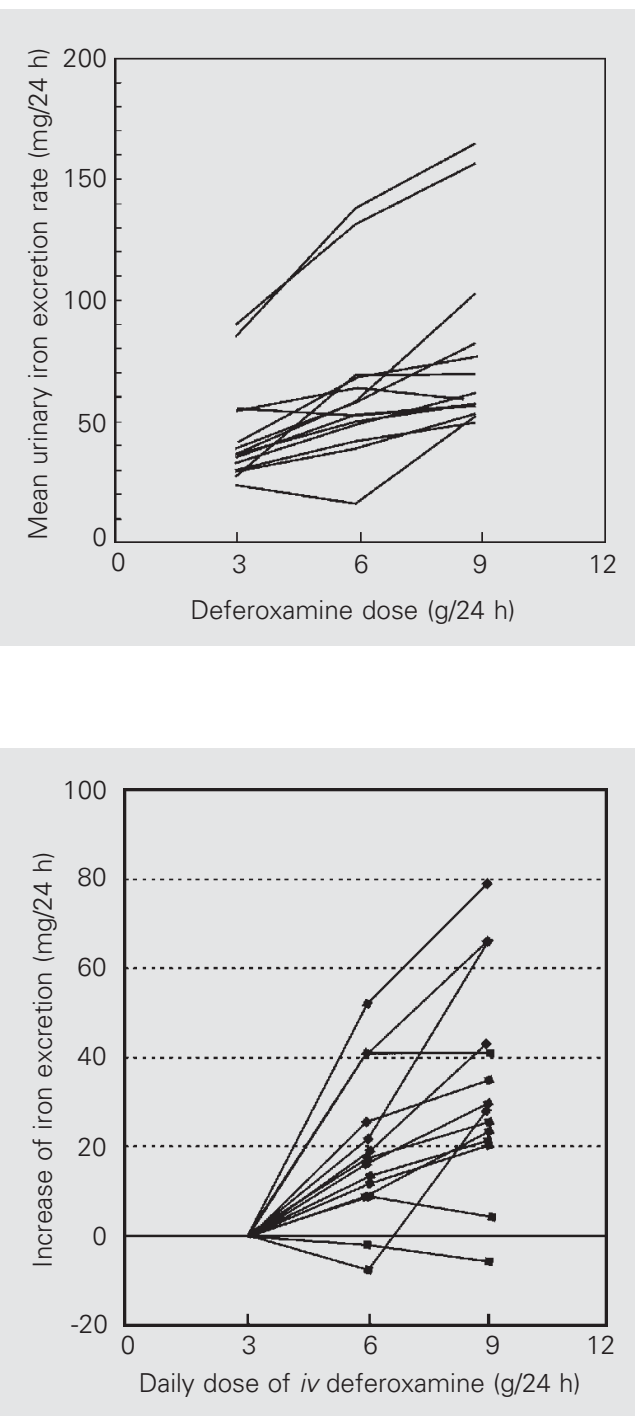

Figure 1. Effect of intravenous deferoxamine dose on thalassemic patients. Each line corresponds to the mean excretion rate of one patient who received 3,6 , and $9 \mathrm{~g}$ of the chelator for 1-4 days before the dose was changed.
Figure 2. Increase of urinary iron excretion induced by 6 and 9 g/day of intravenous deferoxamine in relation to the excretion obtained with $3 \mathrm{~g} /$ day. Each line corresponds to the mean excretion caused by the dose of chelator for one patient. The average value (mean \pm SEM) for the urinary iron/24 $\mathrm{h}$ for all $\mathrm{pa}$ tients with $3 \mathrm{~g}$ deferoxamine/24 h was $44.52 \pm 20.20 \mathrm{mg}$. 
clear indication of the protection afforded by chelation with DF.

Several indirect approaches have been analyzed in this study to identify the best indicator of overload severity. First, our results show that serum iron concentration and transferrin saturation, even though high in these patients, do not distinguish amongst the various grades of overload. The annual iron balance corrected for body weight also proved to be of limited value. Plasma ferritin level appears to be a better indicator, but grossly increased levels may be observed as a consequence of significant hepatic injury $(31,32)$.

Urinary iron excretion induced by subcutaneous DF (20-60 mg/kg body weight) at home showed a positive correlation with the clinical grade. Urinary iron excretion after a single intramuscular injection of $0.5 \mathrm{~g}$ DF is traditionally used either as an indirect measurement of iron overload or as a diagnostic

Table 5. Overall data from intensive chelation therapy with intravenous deferoxamine (DF) during hospitalization.

\begin{tabular}{|c|c|c|c|c|c|c|}
\hline \multirow[t]{2}{*}{$\begin{array}{l}\text { Patient } \\
\text { No. }\end{array}$} & \multirow[t]{2}{*}{$\begin{array}{c}\text { Age } \\
\text { (years) }\end{array}$} & \multirow[t]{2}{*}{$\begin{array}{c}\text { Annual iron acquired } \\
\text { by transfusion } \\
\text { (g) }\end{array}$} & \multicolumn{2}{|c|}{$\begin{array}{c}\text { Urinary iron } \\
\text { excreted during } \\
\text { hospitalization }\end{array}$} & \multirow[t]{2}{*}{$\begin{array}{c}\text { Total days of } \\
\text { iv DF during } \\
\text { hospitalization }\end{array}$} & \multirow{2}{*}{$\begin{array}{l}\text { Total dose of } \\
\text { DF during } \\
\text { hospitalization } \\
\text { (g) }\end{array}$} \\
\hline & & & (g) & $(\%)^{1}$ & & \\
\hline 11 & 13 & 5.95 & 0.63 & 10.6 & 9 & 60 \\
\hline 12 & 13 & 5.26 & 0.39 & 7.4 & 7 & 54 \\
\hline 13 & 13 & 7.06 & 0.59 & 8.3 & 10 & 62 \\
\hline 14 & 13 & 8.08 & 0.69 & 8.5 & 10 & 63 \\
\hline 15 & 14 & 6.65 & 0.50 & 7.5 & 10 & 66 \\
\hline 17 & 15 & 7.74 & 0.32 & 4.1 & 7 & 54 \\
\hline 18 & 16 & 7.28 & 0.32 & 4.4 & 6 & 45 \\
\hline 19 & 17 & - & 1.10 & - & 8 & 54 \\
\hline 20 & 19 & 6.80 & 0.50 & 7.3 & 9 & 54 \\
\hline 21 & 20 & 6.85 & 0.63 & 9.2 & 10 & 63 \\
\hline 22 & 21 & 7.90 & 1.77 & 22.4 & 12 & 90 \\
\hline 23 & 21 & 8.43 & 0.47 & 5.6 & 10 & 66 \\
\hline 25 & 28 & 6.05 & 0.25 & 4.1 & 6 & 45 \\
\hline 26 & 50 & 6.75 & 0.70 & 10.4 & 10 & 72 \\
\hline
\end{tabular}

${ }^{1}$ Iron excreted as percentage of the amount of iron acquired annually.

Table 6. Summary of statistical significance of iron metabolism measurements for the patients grouped by clinical grade or by compliance with the treatment.

\begin{tabular}{lcc}
\hline & Clinical grade & Compliance \\
\hline Serum iron & NS & NS \\
Transferrin saturation & NS & NS \\
Plasma ferritin & NS & S \\
Total iron gain & NS & S \\
Annual iron balance & NS & NS \\
Urinary iron excretion (3 g DF sc) & $\mathrm{S}$ & $\mathrm{NS}$ \\
Urinary iron excretion (6 g DF im) & $\mathrm{NS}$ & $\mathrm{S}$ \\
Urinary iron excretion (9 g DF iv) & $\mathrm{S}$ & $\mathrm{S}$ \\
Urinary iron excretion increase & $\mathrm{S}$ &
\end{tabular}

$S=$ statistically significant, NS = not significant by the Mann-Whitney rank sum test, with the level of significance being $\mathrm{P}<0.05$. 
test for primary hemochromatosis $(28,33)$. Our data demonstrate that this test may be useful to distinguish between the presence or absence of iron overload, but it is not sufficiently sensitive to identify differences between individuals with heterogeneous iron overloads. Thus, even though the urinary iron excretion induced by the continuous use of $3 \mathrm{~g}$ intravenous DF over a $24-\mathrm{h}$ period increased considerably, it did not significantly correlate with other variables that indicate a more severe iron overload. However, when excretion was induced by $6 \mathrm{~g}$ of intravenous DF, urinary iron excretion was higher in patients with clinical grades III to $\mathrm{V}$, and when it was induced by $9 \mathrm{~g} \mathrm{DF}$, it was significantly higher both in non-compliant patients and in patients with higher clinical grades (Table 6).

The increase of iron excretion induced by larger doses of intravenous DF, measured by the difference between the urinary excretion induced by infusion of 6 or $9 \mathrm{~g} D F$ and that obtained with $3 \mathrm{~g}$ DF, was an efficient method to distinguish amongst the various degrees of iron overload: the differences (when calculated as the absolute increase over the excretion induced by $3 \mathrm{~g}$ ) were significantly higher for the patients with the higher clinical severity grades and for those with the higher transfusional iron gain corrected for body weight. The difference between compliant and noncompliant patients was demonstrable only with the increase of iron excretion obtained when the amount of DF was increased from 3 to $9 \mathrm{~g}$ daily. These observations support the view that the amount of potentially chelatable iron is proportional to the extent of overload and that, in a population of massively overloaded patients, urinary iron excretion is an efficient indirect indicator of the extent of iron overload only when it is induced by high doses of intravenous DF.

Finally, we evaluated the efficiency of the more intensive chelation with continuous intravenous DF as an accessory therapeutic approach for ß-thalassemia homozygote patients. Iron excreted into urine during a 6- to 12-day period of hospitalization using this treatment corresponds to a median of $7.5 \%$ (reaching a maximum of $22.4 \%$ ) of the amount of iron received by transfusion during one year. However, since the amount of iron excreted into the feces can exceed 50\% of the total losses (27), total excretion probably reaches a maximum of $44.8 \%$ and a median value of $15.0 \%$. It is necessary to emphasize the low accuracy of this value since the only value directly measured was daily urinary iron excretion, whereas the other components were only estimated. If the chelation period is prolonged, the effectiveness of this approach could be even greater, especially for patients with high iron overloads. It remains to be demonstrated that the iron mobilization, obtained under these conditions in persons with important tissue injuries, is efficient in preventing the evolution of secondary hemochromatosis. Our results, however, suggest that this approach can be a therapeutic tool for patients with large iron overloads, in addition to chelation with subcutaneous DF carried out at home since the maintenance of high-dose infusions over a period of several days a year can effectively cause the excretion of significant amounts of iron. However, lifethreatening pulmonary complications of this treatment have been reported $(34,35)$, as well as possible auditive and ophthalmic adverse effects $(6,29)$, which should be considered when planning individual treatments. 


\section{References}

1. Olivieri NF \& Brittenham GM (1997). Ironchelating therapy and the treatment of thalassemia. Blood, 89: 739-761.

2. Cohen A (1987). Management of iron overload in the pediatric patient. Hematology/Oncology Clinics of North America, 1: 521-544.

3. Cohen A (1990). Treatment of transfusional iron overload. American Journal of Pediatric Hematology/Oncology, 12: 4-8.

4. Giardina PJ \& Grady RW (1995). Chelation therapy in ß-thalassemia: the benefits and limitations of desferrioxamine. Seminars in Hematology, 32: 304-312.

5. Zurlo MG, De Stefano P, Borgna-Pignatti C, Di Palma A, Piga A, Melevendi C, Di Gregorio F, Burattini MG \& Terzoli S (1989). Survival and causes of death in thalassaemia major. Lancet, 2: 27-30.

6. Fosburg MT \& Nathan DG (1990). Treatment of Cooley's anemia. Blood, 76: 435444.

7. Brittenham GM, Griffith PM, Nienhuis AW, McLaren CE, Young NS, Tucker EE, Allen CJ, Farrell DE \& Harris JW (1994). Efficacy of deferoxamine in preventing complications of iron overload in patients with thalassemia major. New England Journal of Medicine, 331: 567-573.

8. Bronspiegel-Weintrob N, Olivieri NF, Tyler B, Andrews DF, Freedman MH \& Holland FJ (1990). Effect of age at the start of iron chelation therapy on gonadal function in ß-thalassemia major. New England Journal of Medicine, 323: 713-719.

9. Lerner N, Blei F, Bierman F, Johnson L \& Piomelli $S$ (1990). Chelation therapy and cardiac status in older patients with thalassemia major. American Journal of Pediatric Hematology/Oncology, 12: 56-60.

10. Maurer HS, Lloyd-Still JD, Ingrisano C, Gonzalez-Crussi F \& Honig GR (1988). A prospective evaluation of iron chelation therapy in children with severe ß-thalassemia. A six-year study. American Journal of Diseases of Children, 142: 287-292.

11. Wolfe L, Olivieri N, Sallan D, Colan S, Rose V, Propper R, Freedman MH \& Nathan DG (1985). Prevention of cardiac disease by subcutaneous deferoxamine in patients with thalassemia major. New England Journal of Medicine, 312: 16001603.

12. Borgna-Pignatti $C$, Rugolotto $S$, De Stefano P, Piga A, Di Gregorio F, Gamberini MR, Sabato V, Melevendi C, Cappellini MD \& Verlato G (1998). Survival and disease complications in thalassemia major.
Annals of the New York Academy of Sciences, 850: 227-231.

13. Calleja EM, Shen JY, Lesser M, Grady RW, New MI \& Giardina PJ (1998). Survival and morbidity in transfusion-dependent thalassemic patients on subcutaneous desferrioxamine chelation. Nearly two decades of experience. Annals of the New York Academy of Sciences, 850: 469-470.

14. Olivieri NF, Nathan DG, MacMillan JH, Wayne AS, Liu PP, McGee A, Martin M, Koren G \& Cohen AR (1994). Survival in medically treated patients with homozygous ß-thalassemia. New England Journal of Medicine, 331: 574-578.

15. Cianciulli $P$, Forte $L$, Sorrentino F, Palombi M, Papa G \& Marciani MG (1993). Intensive long-term intravenous iron-chelation therapy with deferoxamine in thalassemic patients. Bone Marrow Transplantation, 12 (Suppl I): I-5-I-8.

16. Cohen AR, Mizanin J \& Schwartz E (1989). Rapid removal of excessive iron with daily, high-dose intravenous chelation therapy. Journal of Pediatrics, 115: 151-155.

17. National Diabetes Data Group (1979). Classification and diagnosis of diabetes mellitus and other categories of glucose intolerance. Diabetes, 28: 1039-1057.

18. Caraway WT \& Fanger H (1955). Ultramicro procedures in clinical chemistry. American Journal of Clinical Pathology, 25: 317-321.

19. Ramsay WNM (1957). The determination of iron in blood plasma or serum. Clinica Chimica Acta, 2: 214-220.

20. Pippard MJ \& Stray S (1982). Simple assay for urinary iron after desferrioxamine therapy. American Journal of Clinical Pathology, 77: 324-327.

21. Pippard MJ (1983). Iron loading and chelation therapy. In: Weatherall DJ (Editor), The Thalassemias (Methods in Hematology). Vol. 6. Churchill Livingstone, Edinburgh, UK.

22. Bianco I, Graziani B, Lerone M, Congedo P, Clemente GF, Ingrao G, Ciccone F, Di Nucci GD, Mandelli F \& Isacchi G (1984). A study of the mechanisms and sites of action of desferrioxamine in thalassaemia major. Acta Haematologica, 71: 100-105.

23. Gevirtz NR \& Wasserman LR (1965). Iron metabolism: studies with desferrioxamine. American Journal of Clinical Nutrition, 16: 389

24. Gevirtz NR, Tendler D, Lurinsky G \& Wasserman LR (1965). Clinical studies of storage iron with desferrioxamine. New
England Journal of Medicine, 273: 95-97.

25. Harker LA, Funk DD \& Finch CA (1968). Evaluation of storage iron by chelates. American Journal of Medicine, 45: 105115.

26. Nienhuis AW, Delea C, Aamodt R, Bartter F \& Anderson WF (1976). Evaluation of desferrioxamine and ascorbic acid for the treatment of chronic iron overload. In: Bergsma D, Cerami A, Peterson CM \& Graziano JH (Editors), Iron Metabolism and Thalassemia. Vol. 12 (Birth Defects Original Artical Series). Alan R. Liss Inc., New York, NY, USA, 177-185.

27. Pippard MJ, Callender ST \& Finch CA (1982). Ferrioxamine excretion in ironloaded man. Blood, 60: 288-294.

28. Modell B \& Berdoukas V (1984). The Clinical Approach to Thalassemia. Grune and Stratton, London, UK.

29. Pippard MJ (1989). Measurement of iron status. In: Bucker CD, Gale RP \& Lucarelli $\mathrm{G}$ (Editors), Progress in Clinical and Biological Research: Advances and Controversies in the Thalassemia Therapy-Bone Marrow Transplantation and Other Approaches, 309: 85-92. Alan R. Liss, Inc., New York, NY, USA.

30. Barry M \& Sherlock S (1971). Measurement of liver-iron concentration in needlebiopsy specimens. Lancet, 1: 100-103.

31. Cazzola M, Borgna-Pignatti C, De Stefano $P$, Bergamaschi G, Bongo IG, Dezza L \& Avato $F$ (1983). Internal distribution of excess iron and sources of serum ferritin in patients with thalassaemia. Scandinavian Journal of Haematology, 30: 289-296.

32. Jacobs A \& Worwood M (1975). Ferritin in serum. Clinical and biochemical implications. New England Journal of Medicine, 292: 951-956.

33. Ploem JE, De Wael J, Verloop MC \& Punt $K$ (1966). Sideruria following a single dose of desferrioxamine-B as a diagnostic test in iron overload. British Journal of Haematology, 12: 396-408.

34. Rego EM, Neto EB, Simões BP \& Zago MA (1998). Dose-dependent pulmonary syndrome in patients with thalassemia major receiving intravenous deferoxamine. American Journal of Haematology, 58: 340-341.

35. Freedman $\mathbf{M H}$, Grisaru $\mathrm{D}$, Olivieri $\mathrm{N}$, MacLusky I \& Thorner PS (1990). Pulmonary syndrome in patients with thalassemia major receiving intravenous deferoxamine infusions. American Journal of Diseases of Children, 144: 565-569. 